\title{
PERLINDUNGAN HUKUM TERHADAP REKAM MEDIS PASIEN DI RUMAH SAKIT
}

\author{
Oleh: \\ Made Dwi Mariani
}

\begin{abstract}
Patient as consumers of health service have rights one of the rights is the state of the patients health is being concealed forever including medical data and medical records. Regarding to that, hospital as the health care provider obliged to provide legal protection to all kind of information in the medical record to the possibility of loss of information, data falsification or used by the undue. Based on that, the problem to be studied is: how is the medical record management in the hospital? And how is the medical record legal protection, which is given by the hospital?

This study use normative legal research with statue approach. All of the legal resources based on library research and supported by primary and secondary legal material. Legal research analysis technique in this study use descriptive technique.

The study result showed that the medical record management in the hospital have to based on health minister regulation 269/MENKES/PER/III/2008 about medical records. The management of medical record started from the time patient came to the hospital with record all action that given to the patient until all the treatment completed. The data and information on the medical record, hospital has an obligation of giving legal protection about the confidentiality based on Articles 10 health minister regulation 269/MENKES/PER/ III/2008 with form of preventive and repressive protection.
\end{abstract}

Keywords: Medical Record, legal protection, hospital

\section{Pendahuluan \\ 1.1 Latar Belakang}

Setiap orang selalu menginginkan dalam keadaan yang sehat, karena dalam kehidupan kesehatan merupakan kebutuhan pokok dan salah satu faktor penentu tingkat kesejahteraan seseorang. Begitu pentingnya kesehatan bagi setiap orang maka kesehatan diatur oleh pemerintah melalui peraturan perundang-undangan.

Dalam kaitannya dengan kesehatan tentunya tidak terlepas dari pelayanan kesehatan yang wajib diterima oleh setiap orang. Pelayanan kesehatan merupakan semua upaya yang ditujukkan sebagai upaya dalam memelihara kesehatan, mencegah dan mengobati penyakit bagi setiap orang. Salah satu institusi yang memberikan pelayanan kesehatan adalah rumah sakit.

Rumah sakit memiliki peranan penting dalam menunjang pelayanan kesehatan maupun pelayanan medis. Setiap rumah sakit wajib memberikan pelayanan yang terbaik bagi pasiennya.Dalam memberikan pelayanan terdapat tiga komponen yang terlibat dalam proses pelayanan, yaikni : kualitas pelayanan yang diberikan, siapa 
pihak memberikan pelayanan serta pihak konsumen yang memberikan penilaian melalui harapan yang diinginkan. ${ }^{1}$

Pelayanan kesehatan rumah sakit pada dasarnya dilakukan dalam bentuk pengobatan dan perawatan, yang dalam pelaksanaanya sering berhubungan dengan dokter. Dokter dengan pasien memiliki hubungan yang erat, yaitu dalam hubungan medis akan diatur dengan kaidah-kaidah medis dan sebagai hubungan hukum akan diatur oleh kaidah-kaidah hukum. Hubungan antara para pihak tersebut bersumber dari perjanjian terapeutik. Perjanjian Terapeutik merupakan hubungan hukum dalam bentuk kesepakatan antara dokter dengan pasien dalam hal pelayanan kesehatan. ${ }^{2}$

Pada saat seseorang berobat ke rumah sakit, sebenarnya telah terjadi kontrak terapeutik atas dasar rasa percaya kepada dokter untukmampu mengobatinya sekaligus menjaga kerahasian semua hal yang diketahuinya yang berkaitan dengan kondisi kesehatannya. Dalam hubungan yang terjalin tersebut maka secara otomatis, dokter dan tenaga kesehatan lainnya akan mengetahuinya yang nantinya data tersebut dituangkan dalam bentuk tulisan yang dikenal dengan rekam medis. Rekam medis salah satu fungsinya dapat digunakan sebagai alat bukti terhadap proses pelayanan kesehatan yang diberikan kepadapasien.

Terhadap hal tersebut segala data dan informasi yang terdapat didalamnya wajib untuk dijaga kerahasiaanya oleh petugas

Titik Triwundari, 2010, Perlindungan Hukum Bagi Pasien, Prestasi Pustaka, Jakarta, hlm.1.

Annya Isfandyrie, 2006, Tanggung Jawab Hukum dan Saksi bagi Dokter, Prestasi Pustaka, Jakarta, hlm.57. kesehatan termasuk rumah sakit, kecuali yang ditetukan lain oleh UU. Rekam medis secara yuridis juga dapat dipergunakan sebagai alat bukti pada perkara hukum.

Saat ini banyak pasien yang tidak tahu dan tidak perduli akan pentignya rekam medis. Pada saat berobatkerumah sakit pasien hanya mementingkan kesehatan dirinya tanpa mementingan hal lainnya seperti catatan riwayat penyakitnya. Terhadap hal tersebut, sebagai institusi pelayanan kesehatan rumah sakit memiliki kewajiban untuk menjaga seluruh infomasi yang terdapat dalam rekam medis. Secara hukum rumah sakit sebagai pemilik segala catatan yang ada dirumah sakit, termasuk rekam medis. Rumah sakit bertanggung jawab secara moral dan hukum terhadap segala kerahasiaan isi dari informasi yang dimuat dalam catatan medik, sehingga berupaya untuk memjaga dan memberikan perlindungan agar tidak sampai mengalami informasi tersebut tidak sampai diketahui oleh pihak yang tidak berwenang. Perlindungan data rekam medis diberikan oleh rumah sakit, sejak pasien masuk, selama pasien dirawat dan sesudah ia pulang.

Perlindungan hukum merupakan perlindungan yang diberikan oleh hukum terhadap hubungan hukum dalam masyarakat yang diatur sesuai dengan ketentuan hukum. Dalam hal ini maka hubungan yang terjadi antara rumah sakit, dokter dan pasien dilindungi oleh hukum termasuk salah satu kegiatan yang dilakukan berupa pencatatan riwayat kesehatan pasien. Berdasarkan hal tersebut rumah sakit beserta dokter memiliki kewajiban untuk menyimpan kerahasiaan yang dicatat dalam rekam medis. 


Berdasarkan uraian $\begin{array}{r}\text { latar } \\ \text { akan }\end{array}$
belakangdiatas,maka penulis
mengkajinyake dalam suatu penelitian
dengan judul“Perlindungan Hukum
Terhadap Rekam Medis Pasien di Rumah
Sakit”.
1.2 Rumusan Masalah
1. Bagaimana tata cara penyelenggaraan
rekam medis pasien di rumah sakit?
Bagaimana bentuk perlindungan
hukum terhadap rekam medis pasien
yang diberikan oleh rumah sakit?

\subsection{Tujuan Penelitian}

Untuk mengetahui dan menganalisis terhadap penyelenggaraan rekam medis di rumah sakit serta bentuk perlindungan hukum terhadap kerahasiaan rekam medis di rumah sakit.

\section{Metode Penelitian}

Penelitian hukum yang penulis gunakan dalah penelitiannormatif. Digunakan metode ini,oleh karena penelitian ini mengkajisumber hukum sebagai dasar dalam penyelesaian masalah penelitian ini dan juga dimulai dengan dilakukan penelitian terhadap norma hukum yang ada kaitannya dengan permasalahan. Berkaitan dengan permasalahan tersebut, maka pendekatan yang digunakan adalah perundang-undangan. Kajian hukum normatif dalam penelitian menggunakan bahan hukum primer, bahan hukum sekunder, dan bahan hukum tersier. ${ }^{3}$

Bahan hukum primer terdiri dari peraturan perundang-undangan, catatan resmi ataupun risalah putusan hakim. ${ }^{4}$ Bahan hukum primer yang dalam penelitian ini meliputi : KUHPerdata, KUHP, UU Praktik Kedokteran, UU Kesehatan, Permenkes No. 269/MENKES/PER/III/2008tentangRekam Medis, Permenkes No. 290/MENKES/ III/2008 tentang Persetujuan Tindakan Kedokteran, PP No. 10 Tahun 1966 tentang Wajib Simpan Rahasia Kedokteran. Bahan hukum sekunder berupa literatur hukum, majalah dan karya tulis yang berkaitan dengan permasalahan dalam penulisa ini.Teknik pengumpulan Bahan hukum dilakukan secarastudi dokumen dengan mengkaji serta mengumpulkan tentang berbagai dokumen yang sudah ada. ${ }^{5}$ Selanjutnya akandisajikan melalui deskriptif-analitis.

\section{Hasil dan Pembahasan \\ 3.1. Penyelenggaraan Rekam Medis Milik Pasien Oleh Rumah Sakit}

Berdasarkan UU Rumah Sakit, rumah sakit merupakan suatu institusi yang menyediakan pelayanan kesehatan perorangan secara paripurna. Terhadap pelayanan kesehatan tersebut, rumah sakit memilki kewajiban untuk menyelenggarakan rekam medis. Rumusan Rekam Medis menurut Permenkes adalah suatu berkas yang memuat tentang dokumen terkait data diri pasien, pemeriksaan, pengobatan,tindakan perawatan dan pelayanan yang diteriman oleh pasien.

Soerjono Soekanto \& Sri Mamudji, 2006, Penelitian Hukum Normatif Suatu Tinjauan Singkat, Raja Grafindo Persada, Jakarta, hlm. 13.

Peter Mahmud Marzuki, 2006, Penelitian Hukum, Kencana, Jakarta, hlm.141.

Salim, 2013, Penerapan Teori Hukum Pada Penelitian Tesis dan Disertasi, Raja Grafindo Persada, Jakarta, hlm.19. 
Dari sudut hukum, menurut Hermien Hadiati Koeswadji, ada dua hak asasi manusia yang menjadi dasar dalam hukumkedokteran, yaitu hak atas pemeliharaan kesehatan (the right to healthcare) dan hak untuk menentukan nasib sendiri (the right to selfdetermination atau zelf-beschikkingrecht $)^{6}$ Lebih lanjut, beliau mengemukakan bahwa dalam melakukakntransaksi terapeutik ada dua macam hak asasi manusia yang menjadi dasar, yaitu hak untuk menentukan nasib sendiri dan hak untuk mendapatkan informasi. Kedua hak tersebut berlawanan dengan hak atas perawatan kesehatan (the right to healthcare) yang termasuk dalam hak asasi bagi setiap orang.Terhadap hal tersebut, keberadaan hubungan antara dokter dengan pasien, baik ditinjau dari sudut hukum maupun aspek pelayanan kesehatan, tidak terlepas dari hak asasi manusia yang ada pada setiap manusia, khususnya hak dalam menentukan nasibnya sendiri dan hak untuk memperoleh pelayanan kesehatan. ${ }^{7}$

Salah satu hak asasi dari pasien yang merupakan kewajiban dari dokter sebagaimana yang tertuang pada Pasal 45 ayat (1) dan (2) UU Praktik Kedokteran adalah bahwa untuk terjadinya perikatan hukum dokter dengan pasien, penawaran itu harus diikuti dengan penjelasan secara lengkap mengenai berbagai hal seperti diagnosis dan terapi oleh dokter. Apabila kemudian pasien memberikan persetujuan untuk pengobatan atau perawatan maka terjadilah perikatan hukum yang dikenal dengan kontrak terapeutik atau transaksi

Triana Ohoiwutun, 2007, Bunga Rampai Hukum Kedokteran, Penerbit Bayu Media, Malang, hlm.7.

Ibid. terapeutik.

Terjalinnya kontrak terapeutik maka akan menimbulkan hubungan hukum bagi dokter maupun pasien, salah satunya dalam bentuk hak untuk dirahasikan selamanya tentang keadaan kesehatan termasuk datadata medis yang dimilikinya hal tersebut berkaitan dengan keberadaan rekam medis pasien. $^{8}$

Dibuatnya data rekam medis oleh rumah sakit memilki tujuan salah satunya untuk mendapatkan data berupa catatan ataupun dokumen yang akurat dan adekuat milik pasien, yang didalamnya memuat tentang riwayat kesehatan, riwayat penyakit baik dimasa lalu dan sekarang, juga berupa pengobatan yang telah diberikan. Selain itu, dibuatnya rekam medis juga sebagai sarana tertib administrasi pada rumah sakit, yang dapat sebagai faktor penentu dalam rangka usaha untuk meningkatkan pelayanan kesehatan. $^{9}$

Tata cara pengelolaanrekam medismerupakan salah satu faktor penentu mutupelayanan padainstitusi kesehatan, maka akan mendapat penilaian tentang mutu dan standar pelayanan apa sudah sesuai dengan ketentuan. Oleh karena itu, pemerintah mengatur penyelenggaraan catatan medik dalam suatu Peraturan Menkes. PengolahanRekam medikdiatur dalamPeraturan Menteri Kesehatan Nomor 269 tahun2008, yaitu :

1. Dalam Pasal 5 ayat (2) dinyatakan bahwa Rekam mediswajib untuk segera

Ibid, hlm. 9 .

Ery Rustiyanto, 2009, Etika Profesi Perekam Medis dan Informasi Kesehatan, Penerbit Graha Ilmu, Yogyakarta, hlm.6. 
dibuatkanserta dilengkapi seluruh datanya setelah pasien menerima pelayanan. Hal tersebut dilakukan dengan tujuan agar berupa data asli dan tak satupundata yang terlupakan karena hal tersebutmemilikijangka waktu.

2. Pada Pasal 5 ayat (4) menyatakan bahwa setiap mencatat wiwayat pasien wajib menuliskan nama serta membubuhkan tanda tangan petugas kesehatan, dengan tujuan untuk dapat memudahkanpertanggungjawaban pencatatan data pasien.

3. Selanjutnya dalam Pasal 5 ayat (5) menyatakan bahwa apabila terdapat kesalahan pencatatan pada rekam medis, maka dapat dilakukan pembetulan. Dalam ayat (6) dijelaskan bahwa pembetulan dilakukan dengan pencoretan dengan tidak menghilangkan catatan yang diperbaiki dan tetap membubuhkan paraf tenaga kesehatan yang bersangkutan.

Sebagaimana rumusan Pasal 46 ayat (1) UU Praktik Kedokteran yang menegaskan bahwa dokter dan dokter gigi memiliki kewajiban untuk membuat catatan medissaat melakukantindakan kedokteran. Setelah dilakukanya tindakan kepada pasien, paramedisdengan segera harusmelengkapi datarekam medis dengan menuliskanseluruh tindakankesehatan yang diberikannya kepada pasien.

Apabila dalam pencatatan rekam medis terjadi kesalahan, maka catatan tersebut tidak diperbolehkan hilang atau terhapus. Dalam hal perubahan rekam medis yang terjadi kesalahan,petugas kesehatan yang bersangkutan mencoret bagian yang salah dan kemudian dibubuhi parafnya.

\subsection{Perlindungan Hukum Oleh Rumah Sakit Terhadap Kerahasiaan Rekam Medis Pasien}

Rahasia dari data rekam medis seorang pasien wajib dijaga dengan baik oleh rumah sakit sebagai organisasi yang menyimpan keberadaan rekammedis, selain itu kewajiban ini juga harus dilakukan oleh tenagakesehatan sebagai pihak yang terlibat dalam proses pembuatannya. Menurut Hanafiah, rahasia diartikan sebagai menyembunyikan suatu hal yang hanya boleh satu orang atau beberapa orang saja atau kalangan tertentu untuk mengetahuinya ${ }^{10}$ Sedangkan kerahasiaan (confidentiality) adalah proteksi terhadap rekam kesehatan dan informasi lain pasien dengan cara menjaga informasi pribadi pasien dan pelayanannya. Dalam pelayanan kesehatan, informasi itu hanya diperuntukkan bagi pihak tenaga kesehatan yang berwenang. ${ }^{11}$ Hal seperti inilah yang akhirnya memberikan kewajiban untuk menyimpan rahasia tentang keadaan pasien.

\section{Sesuai dengan ketentuan Pasal} 12 Permenkes No.269 thn 2008 bahwa terhadap substansi dari Rekam Medismerupakankepunyaan dari pasien, sedangkan berkas catatan mediksecara wujudnya merupakan milik dari instansi

10 Alexandra Indriyanti Dewi,2008, Etika dan Hukum Kesehatan, Penerbit Pustaka Book, Yogyakarta, hlm.254.

11 Budi Sampurna, dkk. 2008, Pedoman Manajemen Informasi Kesehatan Di Sarana Pelayanan Kesehatan, Penerbit Universitas Indonesia, Jakarta, hlm.87. 
kesehatan. Sebagai konsekuensi dariisi Rekam Medis merupakan kepemilikan dari pasien, maka tidak ada suatu alasan bagidokter ataupuntenaga kesehatan untuk menolak memberitahukannya pada pasien, kecuali dalamkondisi yang ditentukan lain. Oleh sebab data rekam medis kepunyaan dariinstansi kesehatan, maka pasien tidak diperkenankan untuk meminjam tanpa ijin pihak rumah sakit.

Isi pada rekam medis meliputi dua jenis data, yaitu: ${ }^{12}$

1. Data medis atau data klinismerupakan seluruh kumpulaninformasi tentang riwayat penyakit, pengobatan serta hasilnya, hasil pemeriksaan kesehatan. Data ini sifanya rahasia (confidential) sehingga harus dijaga kerahasiaannya dan tidak boleh pihak lain mengetahuinyaterkecuali apabila ada sebablain berdasarkan perundanganundangan.

2. Data sosiologis atau data nonmedis adalah seluruh informasi selain dengan informasi medis. Oleh sebagian pihak, data tersebut dianggap tidak rahasia, namun beberapa diantaranya menyatakan data tersebut bersifat rahasia (confidensial).

Informasi dalam rekam medis harus mendapatkan perlindungan hukum. Perlindungan hukum merupakan segala peraturan hukum yang diberikan oleh masyarakat didasari melaluipersetujuan kehendak masyarakat untuk mengatur hubungan dan tingkah lakuanggota masyarakat dengan pemerintah yang

$12 \quad$ Ibid, hlm.17. mewakilikepentingannya. ${ }^{13}$ Satijipto Raharjo berpendapat bahwa perlindungan hukum merupakan perlindungan terhadap HAMyang diberikan kepada seluruh pihakuntuk dapat menikmati seluruh hak yang diberikan oleh hukum. ${ }^{14}$ Sedangkan menurut Pjillipus M. Hadjon bahwa perlindungan hukum bagi rakyat sebagai tindakan pemerintah yang bersifat preventif sebagai upaya untuk dapat menghidariterjadinya pelanggaranyang terdapat dalam peraturan perundangundangan dan yang bersifatSedangkan represif yang merupakanperlindungan terakhirdalam wujudpertanggung jawab perusahaan, denda, penjara dan hukuman tambahan yang diberikan apabila terjadi pelanggaran. ${ }^{15}$ Terhadap data rekam medis yang dimiliki pasien, rumah sakit beserta tenaga kesehatan memiliki kewajiban untuk memberikan perlindungan secara hukum.

Perlindungan secara preventif yang diberikan oleh pemerintah dalam hal ini diwakili oleh rumah sakit dimuat dalam ketentuan Pasal 57UU Kesehatan bahwa pasien berhak atas rahasia kedokteran. Adapun hal-hal yang harus dirahasiakan itu menurut Peraturan PemerintahTentang Wajib Simpan Rahasia Kedokteran meliputi semua hal yang diketahui saat melakukan pekerjaan kedokteran. Berkaitan dengan hal itu, semua yang diketahui ialah segala kenyataan yang diperoleh saat pemeriksaan, interprestasi untuk memberikan diagnosis untuk memberikan pengobatan. Hal ini

\footnotetext{
13 Satijpto Raharjo, 2000, Ilmu Hukum, PT. Citra Aditya Bakti, Bandung, hlm. 69. Ibid, hlm.54.

15 Pjillipus M. Hadjon, 1988, Perlindungan Hukum Bagi Rakyat, Bina Ilmu, Surabaya, hlm.5.
} 
meliputi anamnesa, pemeriksaan jasmani, pemeriksaan dengan alat-alat kedokteran, fakta yang dikumpulkan oleh pembantupembantunya dan sebagainya.Hal tersebut dapat menjadi dasar bahwa seluruh informasi data yang terdapat dalam rekam medis sifatnyakonfidensial. Pada dasarnyarekam medisadalah keseluruhaninformasi yang dipergunakan untuk segala kepentingan.Oleh karena data tersebut bersifat konfindensial maka terhadap penarikan, pemaparan ataupun penggunaan data informasi untuk berbagai kepentingannyadiperlukan untuk memperhatikan aspek hukumnya.

Perlindungan hukum lainnya secara preventif yang dapat dilakukan oleh rumah sakit dengan menjaga keamanan, dalam menyimpan data/informasi unsur keakuratan data/informasi dan kemudahan akases menjadi tuntutan pihak organisasi pelayanan kesehatan, praktisi kesehatan serta pihak ke-3 yang berwenang. Sedangkan privasi pasien harus dihormati oleh pihak yang memerlukaninformasi. Dengan begitu, berbagai pihak yang berwenang yang membutuhkan data/informasi yang lebih rinci sesuai dengan tugasnya harus senantiasa menjaga keempat unsur di atas.

Rumah sakit sebagai manajemen informasi kesehatan (MIK) memiliki tanggung jawab professionalantara lain adalah memastikan bahwa privasi dan kerahasiaan informasi pasien terlindungi serta melakukan pengamanan data tersebut. Selain itu tanggung jawab professional MIK juga menjamin pengeluaran peraturan dan prosedur yang akurat dan terbaru. Rumah sakit juga memberikanbentuk pelayanan publik, disamping memiliki kewajiban hukum, rumah sakit juga mendapatkan perlindungan hukum dan tanggung jawab, salah satunya dalam bentuk $:^{16}$

1. Pihak rumah sakit dapat melakukan penolakanuntuk mengungkapkan seluruh informasi kepada umum yang berkaitan dengan rahasia kedokteran ;

2. Bagi pasien/keluarga yang melakukan tuntutan pada rumah sakit dan menginformasikannya pada media massa, maka dianggap sudah melepas hak rahasia kedokterannya kepada umum;

3. Memberikan informasi kepada media massa dapat diartikan sebagai suatu bentuk memberikan wewenang kepada rumah sakit untuk dapat mengungkapkan rahasia kedokteran pasien sebagai hak jawab rumah sakit;

Dalam hal rumah sakit terbukti melakukan keterbukaan informasi rekam medis pasien, maka menimbulkan konsekuensi yuridis bagi rumah sakit untuk bertanggung jawab secara hukum atas pelanggaran yang dilakukan. Hukum yang telah menjadikan rumah sakit sebagai "rechtspersoon", sehingga rumah sakit juga memikul hak dan kewajiban hukum atas perbuatan yang dilakukannya. ${ }^{17}$ Terhadap hal tersebut, rumah sakit sebagai suatu badan hukum, apabila nantinya terjadi tuntutan secara hukum, maka konsekuensi yuridisnya akan ditanggung oleh pihak rumah sakit. Sebagai bentuk perlindungan hukum secara represif, apabila rumah saikit terbukti

Soekidjo Notoatmodjo, 2010, Etika dan Hukum Kesehatan, Penerbit Rineka Cipta, Jakarta, hlm.164. 
membuka infromasi kepada publik maka berdasarkan Pasal 58 UU Kesehatan rumah sakit dapat dituntut ganti kerugian akibat kesalahan atau kelalaian dalam pelayanan kesehatannya termasuk pembocoran rahasia kedokteran. Bentuk perlindungan hukum lainnya dapat berupa pemerian sanksi-sanksi secara perdata, pidana dan administrasi. Rumah sakit pada saat ada tuntutan secara perdata tentang keterbukaan rahasia rekam medis pasien, maka rumah sakit memiliki konsekuensi untuk melakukan pertanggungjawaban secara mutlak dan juga menanggung beban pembuktian pada rumah sakit yaitu pembuktian terbalik. Sedangkan secara tanggung jawab hukum administrasi, rumah sakit dan tenaga kesehatan yang terbukti melakukan pembocoran informasi akan diberikan sanksi administrasi dapat berupa pencabutan ijin atau teguran secara lisan dan tertulis, untuk tanggung jawab hukum pidana maka ketentuan Pasal 322 KUHP menyatakan bahwa dengan sengaja membuka rahasia yang wajib disimpan karena jabatannya dikenakan hukuman penjara selambat-lambatnya sembilan bulan atau denda.

\section{Penutup}

\section{1 Simpulan}

1. Penyelenggaraan rekam medis pasien di rumah sakit sebagaimana diatur dalam ketentuanPermenkes No. 269 Tahun 2008 yang dimulai dari pasien datang ke rumah sakit melakukan

7 Endang Kusuma Astuti, 2009, Transaksi Terapeutik Dalam Upaya Pelayanan Medis Di Rumah Sakit, Penerbit PT. Citra Aditya Bakti, Bandung, hlm.79 pendaftaran sampai pada pasien selesai melakukan perawatan di rumah sakit.

2. Bentuk perlindungan hukum yang diberikan terhadap kerahasiaan rekam medis terdiri dari dua yaitu secara preventif dan represif.

\subsection{Saran}

1. Hendaknya dalam proses penyelenggaraan rekam medis di rumah sakit, tenaga kesehatan yang terlibat harus melaksanakan sesuai dengan ketentuan peraturan perundangundangan ehingga dapat menjaga keamanan, privasi, kerahasiaan dan keselamatan dari informasi yang terdapat didalamnya ;

2. Rekam medis merupakan alat bukti dari catatan yang akurat dan adekuat dari pasien yang sudah seharusnya diberikan perlindungan terhadap informasi didalamnya sehingga pemerintah sudah sewajarnya untuk mengatur secara jelas tentang perlindungan kerahasiaan rekam medis pasien beserta sanksinya yang berat sehingga dapat meminimalisir terjadinya keterbukaan rahasia rekam medis pasien oleh pihak yang tidak berwenang.

\section{Daftar Pustaka}

\section{Buku :}

Astuti,Endang Kusuma, 2009, Transaksi Terapeutik Dalam Upaya Pelayanan Medis Di Rumah Sakit, Penerbit PT. Citra Aditya Bakti, Bandung. 
Dewi,Alexandra Indriyanti, 2008, Etika dan Hukum Kesehatan, Penerbit Pustaka Book, Yogyakarta.

Hadjon,Pjillipus M., 1988, Perlindungan Hukum Bagi Rakyat, Bina Ilmu, Surabaya.

H.S Salim, 2013, Penerapan Teori Hukum Pada Penelitian Tesis dan Disertasi, Raja Grafindo Persada, Jakarta.

Isfandyrie,Annya, 2006, Tanggung Jawab Hukum dan Saksi bagi Dokter, Prestasi Pustaka, Jakarta.

Marzuki,Peter M, 2006, Penelitian Hukum, Kencana, Jakarta.

Notoatmodjo,Soekidjo, 2010, Etika dan Hukum Kesehatan, Penerbit Rineka Cipta, Jakarta.

Raharjo,Satijpto, 2000, Ilmu Hukum, PT. Citra Aditya Bakti, Bandung.

Rustiyanto,Ery,2009, Etika Profesi Perekam Medis dan Informasi Kesehatan, Penerbit Graha Ilmu, Yogyakarta.

Sampurna,Budi, dkk. 2008, Pedoman Manajemen Informasi Kesehatan Di Sarana Pelayanan Kesehatan, Penerbit Universitas Indonesia, Jakarta.

Soekanto,Soerjono \& Sri Mamudji, 2006, Penelitian Hukum Normatif Suatu Tinjauan Singkat, Raja Grafindo Persada, Jakarta.

Triwundari,Titik, 2010, Perlindungan Hukum Bagi Pasien, Prestasi Pustaka, Jakarta.

Ohoiwutun,Triana, 2007, Bunga Rampai Hukum Kedokteran, Penerbit Bayu Media, Malang.

\section{Peraturan Perundang-Undangan :}

Kitab Undang undang Hukum Perdata(KUHPerdata).

Kitab Undang-undang Hukum Pidana (KUHP).

Undang Undang Nomor 29 Tahun 2004 tentang Praktik Kedokteran Lembaran Negara Republik Indonesia Tahun 2004 Nomor 116.

Undang Undang Nomor36 Tahun 2009 tentang Kesehatan Lembaran Negara Republik Indonesia Tahun 2009 Nomor 144.

Undang-Undang nomor 44 Tahun 2009 tentang Rumah sakit Lembaran Negara Republik Indonesia Tahun 2009 Nomor 153.

Peraturan Menteri Kesehatan Repulik Indonesia Nomor 269/MENKES/PER/ III/2008 tentang Rekam Medis.

Peraturan Pemerintah Nomor 10 Tahun 1966 tentang Wajib Simpan Rahasia Kedokteran 